\title{
Peningkatan peran kelompok pendukung gizi balita di masyarakat di masa pandemi Covid-19
}

\author{
Agrina*, Erika, \& Yesi Hasneli \\ Fakultas Keperawatan, Universitas Riau \\ * agrina@lecturer.unri.ac.id
}

\begin{abstract}
Abstrak. Kelompok Balita merupakan kelompok resiko tinggi munculnya masalah gizi di masa pandemi Covid-19 karena kurangnya asupan makan bergizi, kondisi ekonomi yang semakin sulit, dan pelayanan kesehatan balita tidak berjalan selama pandemi Covid-19. Pengabdian ini bertujuan untuk meningkatkan peran kelompok pendukung gizi (kader posyandu) dalam upaya mencegah dan mengatasi masalah gizi balita. Sasaran pengabdian adalah ibu-ibu kader 4 posyandu di kelurahan Sialang Mungu Kota Pekanbaru serta keluarga yang memiliki balita masalah gizi. Metoda pengabdian yang dilakukan adalah pelatihan kader tentang gizi balita, skrining status gizi balita, pendampingan dan lomba membuat bento, pemberian paket dan buku saku gizi balita serta pembuatan aquaponik sebagai upaya ketahanan gizi anak balita di keluarga. Keberhasilan kegiatan ini diukur melalui peningkatan kemampuan kader melakukan pemantauan gizi, berat badan balita antara 500 Gram sampai 1000 Gram pada balita yang mengalami masalah gizi dan keberhasilan pembuatan bento (mengkreasikan makanan). Pelatihan dan pendampingan pada kelompok pendukung gizi mampu memberikan pemahaman yang dibutuhkan dalam mendeteksi gizi balita di masa pandemi covid 19 dan melakukan upaya-upaya perbaikan gizi balita. Pemahaman tentang gizi pada kelompok pendukung gizi tentunya dapat memberikan kontribusi pencegahan dan penyelesaian masalah gizi balita di masyarakat di kota Pekanbaru.
\end{abstract}

Kata kunci: gizi; kelompok pendukung; bento; pelatihan;skrining

\begin{abstract}
The underfive of children is a high-risk group of nutritional problems during the Covid-19 pandemic due to lack of nutritious eating intake, increasingly difficult economic conditions, and child health services (Posyandu) activities were closed. The community service objective was to increase the role of nutrition support groups (posyandu lay workers) in an effort to prevent and overcome nutritional problems for children. The community service targets are 4 posyandu lay workers in Sialang Mungu district, Pekanbaru as well as families with nutritional problems. The method used nutrition training for posyandu lay worker, screening the nutritional status, guidance to make the simple food (bento), providing nutrition packages and making aquaponic as an effort to endurance nutrition.The success of this activity is measured through the increase of posyandu lay workers to perform nutritional monitoring, the success of making bento, and the increase of weight of children between 500 to 1000 grams. Training and mentoring for nutrition support groups was able to provide the necessary understanding in detecting toddler nutrition during pandemic and making efforts to improve the nutrition of children. Nutrition support groups have the main role to prevent and solve the problem of nutrition of children in the community in Pekanbaru.
\end{abstract}

Keywords: nutrition, support group, Bento, training, screening

To cite this article: Agrina., Erika., \& Y. Hasneli. 2020. Peningkatan peran kelompok pendukung gizi balita di masyarakat di masa pandemi Covid-19. Unri Conference Series: Community Engagement 2: 402-408. https://doi.org/10.31258/unricsce.2.402-408

\section{(C) 2020 Authors}

Peer-review under responsibility of the organizing committee of Seminar Nasional Pemberdayaan Masyarakat 2020 


\section{PENDAHULUAN}

Balita (bawah lima tahun) merupakan kelompok umur yang beresiko tinggi munculnya berbagai masalah kesehatan terutama masalah gizi. Di periode ini, balita membutuhkan asupan nutrisi yang adekuat guna memenuhi kebutuhan gizi untuk tumbuh kembang balita. Apabila asupan gizi tidak memadai pada periode ini maka balita akan menyebabkan masalah gizi (Kemenkes, 2015). Keadekuatan asupan nutrisi balita dapat dilihat dari status gizi balita. Apabila status gizi balita berada dibawah normal maka dapat diprediksi asupan gizi balita tidak cukup. Masalah gizi balita saat ini yang cukup mendapat perhatian adalah masalah stunting. Stunting (tinggi badan rendah) untuk usia 12-24 bulan yang dinilai dari tinggi badan dibandingkan umur balita. Masalah gizi pada balita akan berdampak dalam jangka pendek seperti gangguan pertumbuhan dan perkembangan dan berdampak jangka panjang terhadap daya kemampuan anak saat sekolah serta dapat mengurangi produktivitas pada saat dewasa (Stewart, 2013). Masalah gizi pada balita juga dapat dapat meningkatkan risiko kematian pada anak.

Masalah gizi yang dialami balita disebabkan berbagai faktor seperti kurangnya pemenuhan gizi balita akibat pola makan balita, kebiasaan makan yang diterapkan serta disebabkan karena infeksi (Damayanti, 2017; Pelletier, 1995). Pola makan adalah pengaturan jumlah dan jenis makanan guna memenuhi status nutrisi (Adriani \& Wirjatmadi, 2016). Pemberian makan pada balita perlu memperhatikan penyusunan menu, pemilihan dan pengolahan bahan makanan serta penyajian makanan (Rusilanti, Dahlia \& Yulianti, 2015). Pola makan yang baik yaitu pengaturan dan pemberian makan dengan menu yang bervariasi (Isnaini, 2016). Penelitian yang dilakukan oleh Laila, Zainuddin dan Junaidi (2018) menyebutkan pola makan yang buruk dipengaruhi oleh pemilihan makanan untuk balita yang kurang tepat seperti makanan yang mengandung lemak dan makan makanan jajan setiap hari. Pengetahuan ibu menjadi faktor yang mempengaruhi pola makan balita (Arifin, 2015). Ibu dengan pengetahuan yang kurang akan sulit membiasakan pola makan yang baik pada balitanya karena ibu tidak memahami tentang makanan bergizi yang baik untuk balitanya sehingga akan menyebabkan masalah gizi pada balitanya.

Status gizi anak juga ditentukan oleh praktik pemberian makan orang tua. Penelitian Agrina, dkk (2017) menunjukkan bahwa masalah makan pada balita dipengaruhi oleh praktik pemberian makan oleh orang tua. Penelitian lain menyebutkan bahwa ibu cenderung terbiasa memberikan makan yang anak sukai tanpa melihat kandungan gizi makanan tersebut sehingga berpengaruh pada pola makan dan status gizi anak (Mardiana, 2018). Hasil penelitian Damayanti (2017) menunjukkan bahwa jika pola makan balita kurang maka bisa beresiko mengalami masalah gizi kurang. Dapat disimpulkan bahwa berbagai faktor menjadi penyebab munculnya masalah gizi pada balita terutama penyebab utamanya adalah kurangnya konsumsi makanan bergizi akibat faktor pola asuh orangtua dan faktor ekonomi disamping faktor lainnya seperti faktor kesehatan lingkungan dan lain-lain.

Masalah pemenuhan gizi balita di Indonesia saat ini masih menjadi masalah yang belum dapat dituntaskan (masalah utama) yang ditandai dengan jumlah kejadian balita gizi kurang dan buruk di Indonesia masih terbilang besar. Lebih dari sepertiga (37\%) anak-anak berusia kurang dari lima tahun di Indonesia mengalami masalah gizi (stunting) pada 2013 dan prevalensi melebihi (40\%) di 15 dari 33 provinsi.Provinsi Riau merupakan provinsi yang angka kasus gizi kurang dan buruk termasuk kedalam angka yang cukup tinggi yaitu gizi buruk 1,1\%, meningkat sedikit dibandingkan dengan hasil Pemantauan Status Gizi tahun 2015, yaitu $1,03 \%$. Begitu juga dengan beberapa kota dan kabupaten memiliki angka gizi kurang dan buruk cukup signifikan.

Faktor ekonomi juga mempengaruhi kejadian masalah gizi balita karena tersedianya bahan pangan yang bergizi dipengaruhi oleh ekonomi seseorang. Masalah gizi pada balita ini semakin meningkat dengan adanya pandemi Covid-19. Selama pandemi banyak kesulitan yang dialami oleh masyarakat terutama dari aspek ekonomi akibat terjadi pembatasan berbagai aktivitas ekonomi dan daya beli masyarakat menurun. Disamping itu juga pelayanan kesehatan balita mengalami kendala akibat ditutupnya kegiatan posyandu sebagai tempat pemantauan tumbuh kembang balita. Berbagai faktor tersebut diprediksi terjadi penambahan kasus gizi kurang dan buruk pada balita di masyarakat terutama di masa pandemi Covid-19. Permasalahan gizi balita perlu ditangani dengan tuntas dan komprehensif karena akan mempengaruhi status kesehatan balita yang berdampak terhadap pertumbuhan dan perkembangan. Kualitas pertumbuhan dan perkembangan balita menjadi hal penting karena akan mempengaruhi status kesehatan periode siklus kehidupan berikutnya (intergenerational impact) (Soetjiningsih, 1998). Beberapa penanganan yang dapat dilakukan sebagai upaya menyelesaikan masalah gizi adalah memberikan kesempatan untuk memperoleh pelayanan gizi dan kesehatan, serta pemberdayaan masyarakat miskin untuk memperoleh pangan yang mudah. Persoalan gizi kurang dan buruk 
pada balita belum dapat terselesaikan karena kurang memberdayakan masyarakat dan kurang memanfaatkan sumber daya yang ada di masyarakat (Soekirman, 2007). Oleh sebab itu perlu adanya peningkatan pemberdayaan masyarakat dengan meningkatkan peran serta masyarakat khususnya kelompok kader posyandu dalam pencegahan dan penyelesaian masalah gizi balita.

Berdasarkan wawancara dari petugas gizi Puskesmas Sidomulyo Rawat jalan diketahui bahwa masalah gizi kurang (stunting) merupakan masalah utama saat ini. Selama pandemi Covid-19 kegiatan posyandu tidak berjalan dan banyak balita yang tidak terpantau status gizinya selama lebih kurang 4 bulan. Lebih lanjut, belum semua kader posyandu sebagai kelompok yang mendukung upaya gizi di masyarakat mendapatkan pelatihan tentang deteksi gizi balita dan upaya-upaya pencegahan masalah gizi balita. Program pengabdian ini difokuskan kepada ibu-ibu kader posyandu yang wilayah kerja puskesmas khususnya di kelurahan Sialang Munggu Pekanbaru berdasarkan pertimbangan dan kondisi yang ada. Ditambah di wilayah ini jumlah bayi cukup banyak dengan sosial ekonomi masyarakat yang bervariasi. Mayoritas pekerjaan ibu adalah ibu rumah tangga namun didapatkan juga ibu pekerja baik sebagai pegawai negeri, swasta dan pedagang. Rata-rata keluarga disana bertipe nuclear family (keluarga inti), tinggal dengan suami namun masih ditemukan tinggal bersama orang tua. Kegiatan pengabdian ini dirancang guna menurunkan angka kejadian gizi kurang dan buruk di kelurahan Sialang Munggu sehingga dapat membantu penyelesaian masalah gizi di wilayah Kecamatan Tampan kota Pekanbaru.

\section{METODE PENERAPAN}

Kegiatan pengabdian kepada masyarakat terkait peningkatan peran kelompok kader pendukung gizi menggunakan beberapa metode seperti pelatihan, skrining, dan pendampingan. Pelatihan kader gizi posyandu merupakan kegiatan pertama yang dilakukan pada kegiatan pengabdian ini. Pelatihan ini dirancang untuk mempersiapkan kader posyandu dalam melaksanakan skrining gizi balita sehingga pemahaman kader tentang gizi bertambah dan keterampilan melakukan skrining gizi sudah sesuai dengan yang diharapkan. Kegiatan pelatihan kader posyandu telah dilakukan kepada perwakilan kader posyandu pada 4 posyandu di wilayah kelurahan sialang Mungu. Jumlah kader yang ikut dibatasi mengingat masa pandemi Covid-19. Kegiatan pelatihan ini menggunakan metode ceramah, diskusi dan demonstrasi tentang gizi balita, cara meningkatkan nafsu makan anak dan cara mengukur status gizi balita melalui beberapa parameter. Kegiatan ini bekerjasama dengan Puskesmas Sidomulyo Rawat Jalan Pekanbaru. Skrining gizi balita merupakan rangkaian kegiatan pengabdian yang dilakukan di wilayah masing-masing posyandu. Metoda skrining yang dilakukan adalah pemeriksaan berat badan dan Tinggi badan untuk menentukan status gizi balita. Tahap awal dilakukan di posyandu dan dilanjutkan ke rumah-rumah. Kegiatan skrining yang dilakukan dengan menerapkan protokol kesehatan Covid-19. Kegiatan yang selanjutnya dilakukan adalah pendampingan pembuatan bento. Metoda yang digunakan adalah dengan memasak bersama kader dengan bahan makanan yang telah disiapkan yang kemudian disajikan dengan menarik. Terakhir adalah kegiatan pemberian paket gizi kepada balita yang memiliki 3 indikator pemeriksaan gizi. Paket gizi berisi multivitamin dan biskuit susu. Kegiatan terakhir adalah pembinaan aquaponik sebagai upaya untuk meningkatkan ketahanan gizi keluarga terutama masa pandemi Covid-19. Aquaponik adalah kegiatan dari sistem pertanian yang mengkombinasikan antara akuakultur dan hidroponik dalam lingkungan yang bersifat simbiotik. Dalam akuakultur yang normal, ekskresi dari hewan yang dipelihara akan terakumulasi di air dan meningkatkan toksisitas air jika tidak dibuang. Berikut gambaran kegiatan pengabdian kepada masyarakat, metode yang digunakan dan materi yang diberikan. 
Tabel 1. Gambaran Kegiatan peningkatan peran kelompok pendukung gizi balita di kelurahan Sialang Mungu Pekanbaru

\begin{tabular}{|c|c|c|c|}
\hline No & Kegiatan & Metode & Materi \\
\hline 1. & $\begin{array}{l}\text { Pelatihan dan penyegaran } \\
\text { kader Posyandu tentang } \\
\text { gizi balita }\end{array}$ & $\begin{array}{l}\text { Ceramah, diskusi dan } \\
\text { Role Play }\end{array}$ & $\begin{array}{l}\text { a. Konsep gizi dan masalah gizi balita, } \\
\text { b.Pengukuran dan deteksi tumbuh- } \\
\text { kembang } \\
\text { c. Perawatan balita dengan masalah gizi } \\
\text { termasuk tentang pembuatan bento } \\
\text { d.Pelatihan pemanfaatan lahan } \\
\text { menggunakan sistem aquaponik. }\end{array}$ \\
\hline 2. & $\begin{array}{l}\text { Deteksi gizi/skrining gizi } \\
\text { balita }\end{array}$ & $\begin{array}{l}\text { Pemeriksaan BB/U, } \\
\text { TB/U, dan } \mathrm{BB} / \mathrm{TB} \text {. }\end{array}$ & $\begin{array}{l}\text { Pemeriksaan gizi balita dilakukan di } \\
\text { masing-masing posyandu oleh kader } \\
\text { dengan menerapkan protokol } \\
\text { Kesehatan (menggunakan masker dan } \\
\text { face shield) dan dilanjutkan kunjungan } \\
\text { ke rumah balita door to door. }\end{array}$ \\
\hline 3. & Paket gizi & $\begin{array}{l}\text { Edukasi langsung } \\
\text { kepada ibu balita }\end{array}$ & $\begin{array}{l}\text { Paket gizi terdiri dari Extra Food } \\
\text { sebagai multivitamin alami dan biskuit } \\
\text { susu kerjasama dengan pihak } \\
\text { Puskesmas Sidomulyo Rawat Jalan }\end{array}$ \\
\hline 4. & $\begin{array}{l}\text { Pemberian buku saku } \\
\text { panduan praktis makanan } \\
\text { bergizi untuk balita }\end{array}$ & $\begin{array}{l}\text { Edukasi langsung } \\
\text { kepada kader tentang } \\
\text { gizi balita }\end{array}$ & $\begin{array}{l}\text { Gizi balita, deteksi gizi, bento dan } \\
\text { aquaponik }\end{array}$ \\
\hline 5 & Pembuatan bento & $\begin{array}{l}\text { Demonstrasi langsung } \\
\text { dan masak bersama }\end{array}$ & $\begin{array}{l}\text { Pembuatan makanan bergizi untuk } \\
\text { balita dan mengkreasikan makanan. } \\
\text { Bahan masakan yang digunakan } \\
\text { disediakan yaitu lele, wortel, buncis, } \\
\text { tahu, kentang, telur, tepung terigu, } \\
\text { selada, dan pisang. }\end{array}$ \\
\hline 6. & $\begin{array}{l}\text { Pembuatan dan edukasi } \\
\text { aquaponik }\end{array}$ & $\begin{array}{c}\text { Demonstrasi dan } \\
\text { pendampingan langsung } \\
\text { pembuatan aquaponik }\end{array}$ & $\begin{array}{l}\text { Pemanfaatan lahan menggunakan } \\
\text { sistem aquaponic (lele dan kangkung), } \\
\text { serta demonstrasi pembuatan } \\
\text { aquaponik di } 4 \text { posyandu } \\
\text { menggunakan kolam dan ember besar. }\end{array}$ \\
\hline
\end{tabular}

\section{HASIL DAN KETERCAPAIAN SASARAN}

Kegiatan pengabdian selama lebih kurang 2 bulan telah terlaksana dengan baik. Adapun kegiatan yang telah dilaksanakan pada kegiatan pengabdian adalah kegiatan skrining gizi balita di 3 posyandu dengan menggunakan 3 indikator gizi, peningkatan pemahaman dan keterampilan kader posyandu dalam mendeteksi gizi balita, kader mampu membuat dan menyajikan makanan bergizi yang menarik dan melakukan upaya pembuatan aquaponik sebagai upaya ketahanan gizi di masyarakat, serta peningkatan berat badan balita. Penjelasan hasil dan ketercapaian sasaran lebih dijelaskan secara rinci sebagai berikut:

1. Seluruh balita di 4 posyandu telah dilakukan skrining gizi sebanyak 177 balita. Kegiatan skrining dilakukan oleh kader bersama mahasiswa kukerta integrasi di posyandu dan dirumah-rumah keluarga yang memiliki balita. 42 orang balita teridentifikasi mengalami masalah gizi dengan menggunakan 3 indikator gizi. 


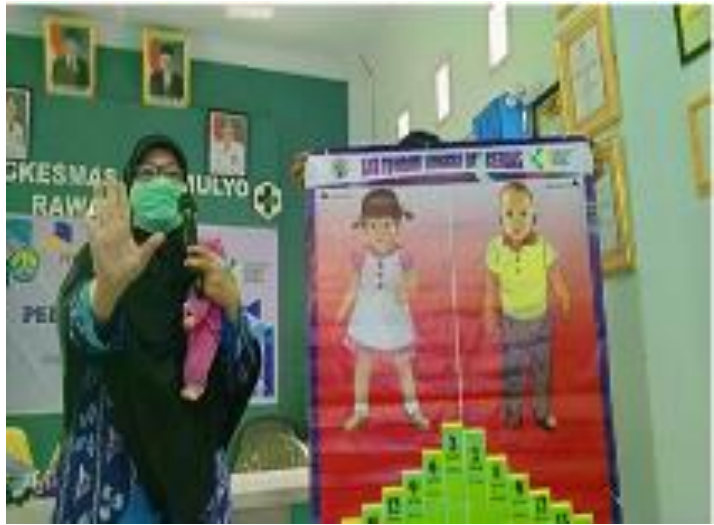

A

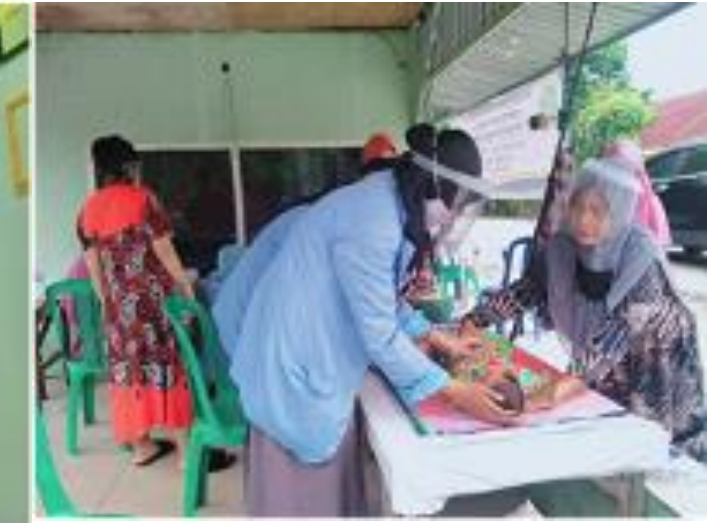

B

Gambar 1. A. Pelatihan kader gizi balita; B. Skrining/ deteksi gizi balita

2. Hasil evaluasi kenaikan berat badan selama dilakukan kegiatan intervensi dari 30 balita yang dipilih didapatkan 22 balita $(73,3 \%)$ mengalami kenaikan berat badan, 2 balita $(6,6 \%)$ tetap berat badan, 4 balita $(13,3 \%)$ turun berat badan, dan $2(6,6 \%)$ tak dirumah saat dievaluasi

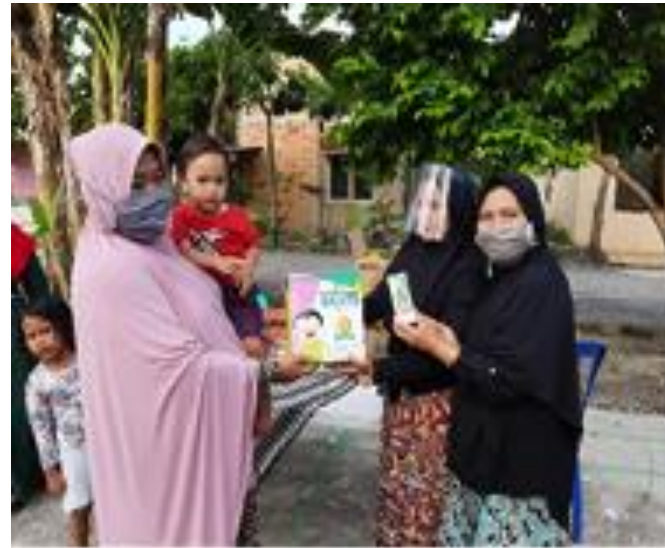

A

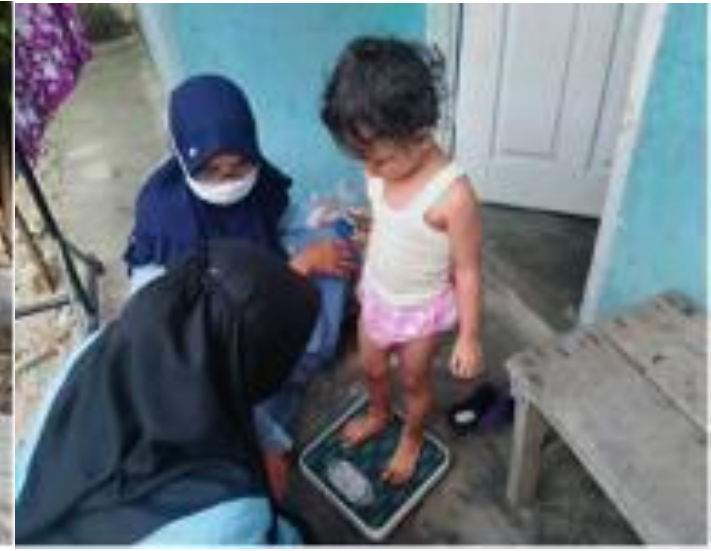

B

Gambar 2. A. Paket Gizi; B. Evaluasi gizi balita

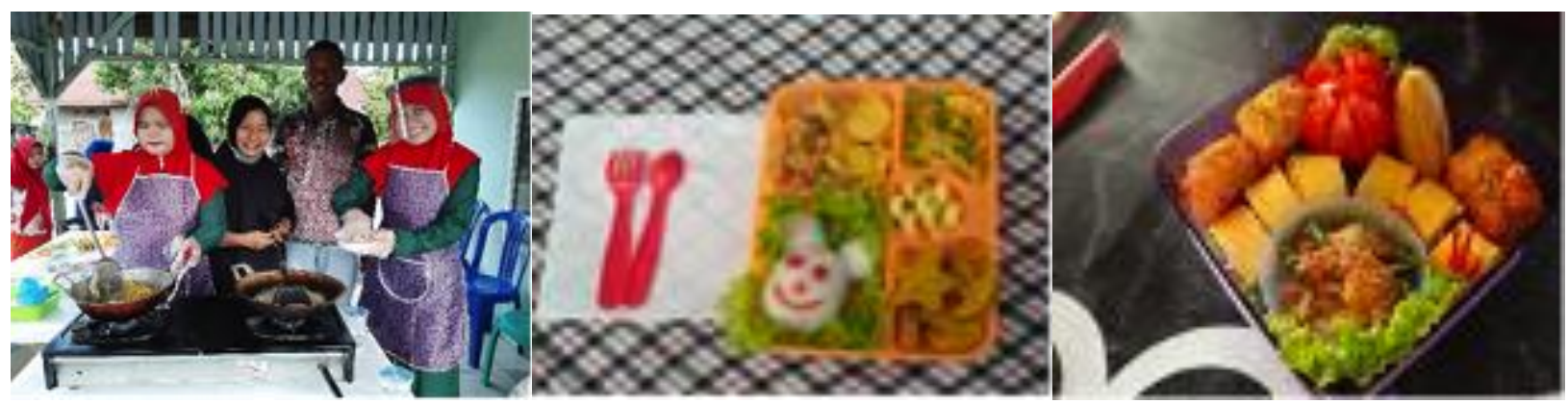

Gambar 3. Pembuatan Bento oleh kader gizi

3. Seluruh kader di 4 Posyandu sudah memiliki kemampuan memasak makan murah dan bergizi serta mampu menyajikan makanan dalam bentuk bento.

4. Aquaponik khususnya ikan lele belum dipanen disebabkan ikan baru bisa dipanen setelah 3 bulan dipelihara, namun demikian saat evaluasi kondisi lele dan sayur kangkung telah mengalami kemajuan ditandai ikan dan sayur semakin besar . 


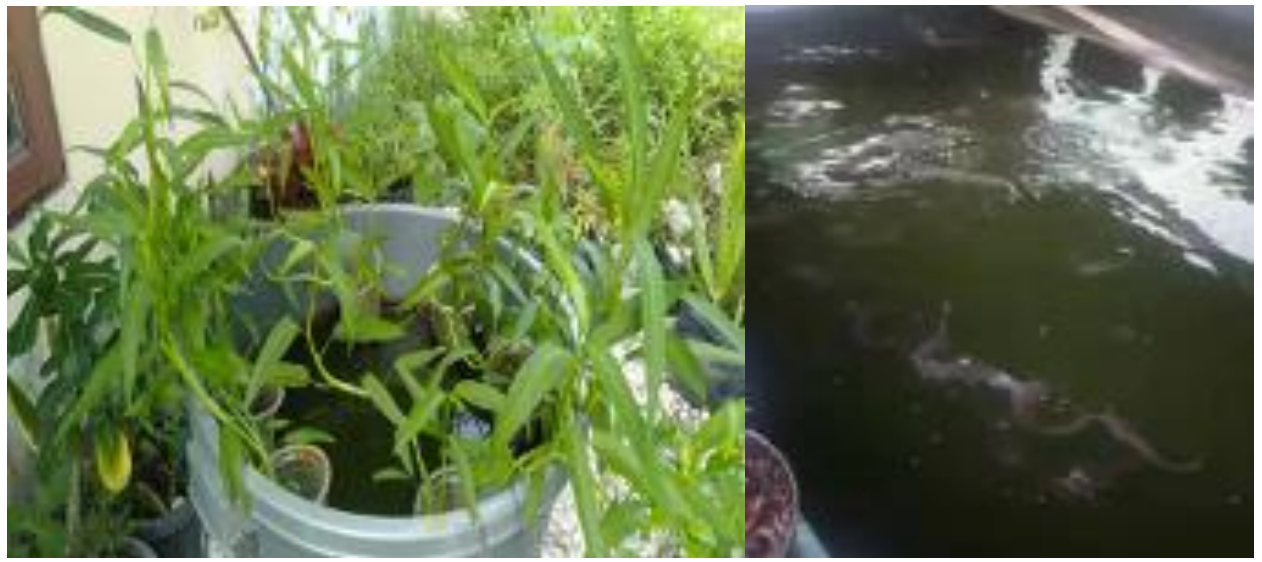

Gambar 4. Pembuatan aquaponik

5. Tersedianya buku panduan pemenuhan gizi balita dan video tutorial tentang pembuatan bento dan aquaponik yang bisa dilihat dengan scan barcode di buku panduan.

\section{KESIMPULAN}

Peran kelompok pendukung gizi balita (kader posyandu) berhasil ditingkatkan guna mencegah dan mengatasi masalah gizi pada balita di masyarakat selama masa pandemi Covid-19. Kader telah mampu melakukan kegiatan pemeriksaan status gizi balita dan melakukan upaya pencegahan dengan menggunakan sumber daya yang ada di masyarakat. Perlu dilakukan upaya lanjut dalam bentuk pendampingan langsung kepada ibu balita dan adanya sistem dalam bentuk aplikasi pemantauan status gizi balita dan konsultasi online mengingat pandemi Covid-19 akan berlangsung lama sehingga masalah gizi balita dapat dicegah dan ditanggulangi.

\section{UCAPAN TERIMA KASIH}

Terima kasih ditujukan kepada LPPM UNRI atas hibah pengabdian kepada masyarakat tahun 2020 sehingga dapat mensupport berbagai kegiatan pengabdian. Ucapan terima kasih juga kepada lurah Sialang Mungu, puskesmas Sidomulyo Rawat Jalan, kader posyandu dan keluarga yang memiliki balita yang telah berpartisipasi dalam kegiatan pengabdian ini

\section{DAFTAR PUSTAKA}

Adriani, M., \& Wirjatmadi, B. 2016. Pengantar Gizi Masyarakat. Jakarta: Kencana.

Agrina, Suyanto, A. 2015. The effect of reading maternal and child health handbook campaign at Posyandu (child health post) in Pekanbaru,Indonesia. The malaysian journal of nursing, 7(2).

Agrina, Omote, S. Tsuda, A. Okuwa, M. Kimura, R. Syahrul. Saito, R. 2017. A Study of Determining Factors of Underweight among toddlers in Riau, Indonesia. Journal of Wellness and Health Care, 41(1), 61-69.

Arifin, Z. 2015. Gambaran pola makan anak usia 3-5 tahun dengan gizi kurang di Pondok Bersalin Tri Sakti Balong Tani Kecamatan Jabon-Sidoarjo. Jurnal Midwiferia, 1(1).

Damayanti, R. 2017. Pengaruh pengetahuan ibu tentang gizi dan pola pemberian makan terhadap kejadian gizi kurang pada balita di wilayah kerja Puskesmas Gajahan Surakarta. Skripsi. Fakultas Ilmu Kesehatan Universitas Muhammadiyah Surakarta.

Isnaini, N. 2016. Hubungan pola asuh, pola makan dan penyakit infeksi dengan kejadian gizi buruk pada balita di kabupaten magetan tahun 2016. Skripsi. Fakultas Ilmu Kesehatan Universitas Muhammadiyah Surakarta

Kemenkes RI. 2015. Status kesehatan anak balita di Indonesia. http://www.depkes.go.id/download.php?file=download/pusdatin/infodatin/infodatin-anak-balita.pdf

Laila, D., Zainuddin, A., \& Junaidi. 2018. Hubungan antara pengetahuan dan pola makan terhadap status gizi lebih pada balita di wilayah kerja Puskesmas Mokoau Kota Kendari tahun 2018. Jurnal Ilmiah Mahasiswa Kesehatan Masyarakat, 3(2). 
Pelletier DL, Frongillo E a J, Schroeder DG, Habicht JP. 1995. The effects of malnutrition on child mortality in developing countries. Bull World Health Organization, 73(4),443-448.

Riskesdas. 2018. Hasil riskesdas 2018.

Rusilanti, Dahlia, M., \& Yulianti, Y. 2015. Gizi dan kesehatan anak prasekolah. Bandung: Remaja Rosdakarya.

Rachmawati, Eka, Mufidah, Lina, dan Sulistiyani Titik. 2020. Pelatihan Pengolahan Bento Untuk Meningkatkan Kreativitas Menciptakan Bekal Makanan, Akademi Kesejahteraan Sosial “AKK”. Yogyakarta.

Soetjiningsih. 1998. Pertumbuhan dan Perkembangan Balita. Jakarta: EGC

Soekirman. 2004. Penyimpangan Positif Masalah keperawatan. http://www.gizinet/cqi

Stewart CP, Iannotti L, Dewey KG, Michaelsen KF, Onyango AW. 2013. Contextualising complementary feeding in a broader framework for stunting prevention. Matern Child Nutr (suppl 2), 27-45.

Widyastuti, Y.R. 2008. Peningkatan Produksi Air Tawar melalui Budidaya Ikan Sistem Akuaponik, Prosiding Seminar Nasional Limnologi IV LIPI, Bogor. 